Global Conferences Series:

Social Sciences, Education and Humanities (GCSSSEH), Volume 2, 2019

The $2^{\text {nd }}$ International Conference on Sustainable Development \& Multi-Ethnic Society

DOI: https://doi.org/10.32698/GCS.0182

\title{
ICT (Information and Communications Technology, or Technologies) Use in Historical Learning
}

\author{
Siti Norba'ayah Ayup', Mohd Mahzan Awang ${ }^{2}$ \& Abdul Razaq Ahmad ${ }^{3}$ \\ ${ }^{123}$ Faculty of Education, MALAYSIA \\ E-mail: snayupsmkis@gmail.com
}

\begin{abstract}
Information and Communication Technology (ICT) is one of the advances used as part of an educational tool, and it has been effectively played between technology and teachers for quality teaching and learning. The purpose of this concept paper discusses the quality of teacher teaching should be maintained so that the field of teaching becomes a professional field and discusses the teaching needs of the 21 st century. This shows how teaching in history subject learning will be more interesting and effective with the use of technology. The technology acceptance model and the designed behaviour theory have been applied to explain the intention of teacher behaviours using technology or ICT at school. Using technology has an impact on how the facts are communicated successfully to the students, and then expose them to the latest and up-to-date information on education. The major issues discussed in this paper are related to the problem that teachers teaching history lessons are teachers who are less skilled in handling the computer for teaching sessions. In addition, there are other constraints constrained such as inefficient computer maintenance systems and adequate of computer room in schools. The above issues are one of the causes that causes historical teachers not to use Web 2.0 in History. The proposed solution is the interaction between the student, the teacher and the administrator, the interaction between the student and the system and the time allocated, the second suggestion is with the technology in building the students' skills in learning history, which in turn is the submission of interesting information in sub topic subject software this history to encourage the interest of the students and thus maintains the student's focus on the entire lesson provided.
\end{abstract}

Keywords: ICT, Historical Learning, Model and the designed behaviour theory

\section{Concept / Definition}

Information and Communication Technology (ICT) (Information and Communication Technology) is the technology required for data processing. The scope of the title is very broad. It may apply to all aspects of

Copyright $\odot$ 2019, the Authors. Published by Redwhite Press. 
information management and processing. The accuracy and ease of use is the use of computers and software to modify, store, protect, process, transfer, view, and obtain information regardless of place and time. Information Technology (IT) and Information and Communication Technology (ICT) are the technology needed for data processing.

As is commonly known, technology is characterized as a form of facilitator that enables the flow of information to be very fast. Actually information technology is not limited to internet and computers only but it involves television, telephones, mobile phones, faxes, telegrams, PDAs and satellite systems in communicating information to recipients. The term "information technology" emerged in the 1970s. In the 20th century, many industries grew rapidly in the wake of the electronics sector, the computing sector, and other technological fields.

There are three important principles in the use of information technology. The first information technology is to collect information. It is used for editing by technology. For example, by using a computer it can record sounds, images and as a motion sensor. Secondly, it is to manipulate the image information and process. Thirdly, it is used to communicate that it explains how information technology is used to communicate to obtain information from sources to recipients.

\section{Theory / Model}

The theory used is based on the Technology Acceptance Model by Davis et al. (1989). Based on the built-in framework has good skill level in Internet usage and minimum constraints in Internet usage which will lead to the achievement of Internet use as R \& D medium in schools. Model of Technology Acceptance (Davis 1989; Davis et al., 1989) deals with the Theory of Reasoned Action (Ajzen \& Fishbein 1980; Fishbein \& Ajzen 1975).

Action Theory Cause expressing trust affects attitudes. This attitude leads to the intention of being translated into behaviour. The Technology Acceptance Model is used to describe the acceptance of users towards the use of technology, especially information systems. This model states that the actual use of a system such as a computer-based system is determined by the user's attitude towards such a system.

Past studies Wong (2002) and Speier et al. (1995), the actual use of a system can be measured based on the user's knowledge and skills on the system. To ensure users are using technology, users first trust or assume a system as useful. Conversely, if the user does not trust the usefulness of the system, the targeted individual will not use that technology. It can therefore be seen that ease of use is not important with the notion of use because the difficulty of using the system can be overcome if the user considers the system useful to him (Davis et al., 1989). Consequently, conceptual frameworks are based on skills, attitudes towards Internet use, and the lack of skills in Internet use are expected to influence the level of Internet usage.

\section{Issue}

The main issue of using ICT in history learning is that teachers who teach historical teaching are less skilled teachers in handling computers for teaching sessions. In addition, there are other constraints such as inefficient computer maintenance systems in schools and adequate computer room problems. The above issues are one of the causes that causes historical teachers not to use Web 2.0 in History learning. Next is a Web History scarcity problem that causes fewer students leveraging the Internet as an alternative that provides access to a variety of helpful information in R \& D. Time management is also one of the factors that causes students not to use computers and the Internet. Use of the Internet requires the right time for students to avoid interrupting their R \& $\mathrm{D}$ processes. This is because Internet usage might take a while to be accessed and accessed.

The second issue is that at the time of globalization today, today's Education is global and is often linked to the achievement of learning outcomes and graduates' marketability. The advancement of communication and information technology (ICT) has made the world community and an organization more connected together in a borderless world community. Education should provide knowledge and skills to create the future generations of the world's society. Education through learning is one of the alternatives that cannot be resisted by all levels of students that are compatible with today's lifestyle that is paperless, Wi-Fi and overdependent on smartphones. Educational institutions should be prepared to change mainly from the aspect of teaching approaches to continue to be accepted by the community and to attract students. Smartphone apps, WhatsApp and Telegram offer an alternative to improving the quality of education as well as the effectiveness of financial management as a result of controls over the needs of human resources and facilities.

\section{Implications}


The implications of technology in the learning of history are demanded because of the 21 st century learning that all multidisciplinary students, acting like computers, are capable of managing knowledge, literacy to new media, smart and proficient thinking and possessing soft skills, namely social intelligence, sensitive, cross-branding culture, open mind and ability to engage in virtual collaboration. Furthermore, this skill is needed to keep abreast of changes in the industry and the world community as a result of industry dependence and service system on smart machines and robots, delivery systems and records that make every activity as a data source and programmed, a way of communicating a new way that in turn makes every organization a mega structured and the world is increasingly linked to each other.

Learning using WhatsApp and Telegram applications is part of the path to meeting the expertise of the workforce required by the industry and the future lifestyle. In addition, social media also provides a good language learning context. Facebook discussions, for example, help students connect with students from abroad who need them to use English correctly. Overall, the effectiveness of Web 2.0 application use in teaching and learning among teachers is a high level with the overall mean score of 3.96 and the standard deviation is 0.611. Based on Table 7, the highest mean is that teachers can send anything in the form of notes, quizzes and exercises easily, interestingly, effectively and with a beautiful and attractive look.

The lowest point is the use of applications such as Facebook, Twitter, Google docs, Skype, slide sharing and others to collaborate on Research and Development. The new approach to Mobile Learning can be applied not only to the learning situation for those who are or who have worked, but also to the situation in primary and secondary levels. In general, the use of tools in Mobile Learning that is more widely available to all groups will help to eliminate illiteracy among the community of tire and rural areas. Its mobile nature or unlimited form of learning at the place and time gives everyone the opportunity to continue their studies and learning. Implementation of Mobile Learning will help reduce illiteracy rates for less developed countries. For countries with high populations and also poor countries, education development requires significant expenditure, especially for the development of infrastructure, educational equipment and payroll of workers. As mobile devices are proven to be cheaper to be used in education, this type of learning approach is more appropriate to help increase literacy of accessory technology in developing countries.

\section{Challenge}

Among the key challenges are the lack of support tools and wireless telecommunications infrastructures in rural areas and the design of learning content that takes into account the cultural aspects. This is because government support, student motivation and the involvement of a potential culture for learning content are among the opportunities that drive the latest technological developments.

According to previous studies Hazwani and Dalbir (2016) have stated the question that mobile technology among students is influenced by two sets of conflicting features ie characteristics as the generation Y and cultural values inherited. For example, as Generation $\mathrm{Y}$ they want to be quick and vocal, but they also highlight the inherent cultural traits that are too dependent on teachers, giving feedback only when asked by teachers and communicating within the group members. In addition to the above challenges there is also a challenge in creating a virtual learning environment or online learning or learning Virtual Learning, there are some challenges that are seen as obstacles to ensuring the success of virtual teaching.

Among the major obstacles identified is the Internet access facility. Norzilawati et al. (2013) states that the speed Internet access issues are an obstacle especially to rural and remote schools with very limited Internet access and prevent teachers from using these facilities optimally. It becomes a dilemma to teachers to implement this facility. Challenges explore the readiness and ability of students to follow learning through WhatsApp and Telegram platforms and explore whether they help students master the learning outcomes.

Students generally are not exposed to mlearning but are ready to learn them and have a positive perspective that the learning can enhance the image of the institution and the skills of graduates. Learning can occur on WhatsApp and Telegram platforms and it helps students master learning outcomes. A more detailed study is needed to know the aspects of self-study and how students and lecturers need to adapt to the various feedback provided by students on WhatsApp and Telegram platforms.

\section{Suggestions For Problem Solving}

Suggestions for problem solving of technology use in historical learning that need to be addressed, namely the interaction between students, teachers and administrators, interactions between students and systems and the time 
allocated for each interaction (Fahad 2010). A cultural aspect that surrounds student thinking needs to be addressed so they are more open and interact positively and build on the WhatsApp and Telegram platforms (Shamsul Arrieya 2011), especially in the early stages of its introduction (Robin 2011).

Further studies have to be done to determine the level of self-learning among students and how history teachers can guide students towards exploring knowledge, meaningful sharing of information and developing the ability to argue on WhatsApp and Telegram platforms. This aspect is important if the lesson is to be introduced to a large-sized group of students so that nothing is just to ride on the platform. The second suggestion of the solution is that the use of multimedia software not only affects the development of student knowledge of a chapter in the lesson but can develop their skills in computer literacy. According to the study of Ros Emiliana (2007) and Lachs (2006), the use of technology in historical learning can also enhance the students' skills in the use of computer literacy. This, by using a computer in learning, can add students' skills in managing computer systems in their daily lives.

The next suggestion is that using the Mobile Learning implementation in the future curriculum is a change to the teacher's own function. Teachers are no longer teaching all week in the classroom but being monitored and facilitated at their own teaching centre. Teachers and lecturers need to have the skills in using all the tools and programs used in Mobile Learning that enable them at the same time to become proficient in planning instruction on learning activities, Hence, related parties must plan ahead before The emergence of such technology in the country includes in terms of training and related courses.

\section{Summary}

Overall, this concept paper has identified the level of knowledge, skill level, attitudes, level of skill constraints, Web 2.0 level of use and the level of effectiveness of Web 2.0 and Internet usage in History. However, keep in mind that technology is only a tool in the Research and development process, it will not be able to replace the teacher's position in a broad sense. Today's education is for future excellence. Students should be prepared to carry out new tasks to develop TMK in learning process.

Students should have shifted from conventional learning methods to dynamic learning in the context of ICT usage. In addition, students should also be prepared to increase their knowledge and skills to make computers as learning technology in place of conventional approaches that are less technology-based (Zamri \& Mohamed Amin 2008). This study is supported by Ida Norini (2013) study on the effectiveness of the concept of VLE Frog's virtual teaching environment among students. He found that all the students, $100 \%$, liked the computer laboratory because they had a new learning atmosphere and from teacher observations they also found students excited when they could enter the computer lab and use this app.

The phenomenon of the TMK wave, has challenged the education system including learning theory to change. The impact is now cyberspace and virtual universities providing learning remotely or online via the World Wide Web (WWW) with the help of TMK tools. Significantly, the speed of application science and the evolution of communication technology has changed the pattern of the community in today's society. Computer-based communications are not limited to disseminating information, but the potential of the technology has become more sophisticated by providing, collecting and processing informational knowledge. Thus, TMK through Internet technology is an important medium in preparing a globally-capable community in the 21 st century.

This is a good start for this student to traverse the increasingly challenging TMK in education. The use of computers as the main medium in the TMK learning process is well received by students. Some changes in the learning process approach apply. Among them is a change of focus from teacher-centred teaching to studentcentred learning (Zamri 2014, Saemah \& Zamri 2017). In this case the student becomes a focus on learning activities oriented to the exploration and discovery process based on the Constructivist Theory approach. TMK's development has created a new flexible learning environment in terms of time, place, method and learning materials, as well as creating more opportunities for greater collaboration processes in the education process. Researchers consider students to take full advantage of the use of virtual learning supplied at school and to attract students to the use of TMK in line with the government's call in order to make education in our country a world-class

\section{References}

[1] Ida Norini Mahamad Tajudin. 2013. Kajian tinjauan mengenai keberkesanan penggunaan konsep persekitaran pengajaran maya frog (VLE Frog) di kalangan pelajar SK Haji Mahmud Chemor, Perak. 
Kertas Projek Penyelidikan. Fakulti Bahasa dan Komunikasi, Universiti Perguruan Sultan Idris.

[2] Rahimah Sabtu. 2013. Penggunaan web 2.0 dalam pengajaran KOMSAS Bahasa Melayu murid sekolah menengah. Kertas Projek Sarjana Pendidikan. Fakulti Pendidikan, Universiti Kebangsaan Malaysia. Saemah Rahman \& Zamri Mahamod. 2017. Inovasi pengajaran dan pembelajaran: Mengoptimumkan pembelajaran pelajar. Kuala Lumpur: Dewan Bahasa dan Pustaka. Sharifah Nor Puteh \& Kamarul Azman. 2011. Tahap kesediaan penggunaan ICT dalam pengajaran dan kesannya terhadap hasil kerja dan tingkah laku pelajar prasekolah. Jurnal Pendidikan Malaysia, 36(1): 25-34.

[3] Shamsudin Mohamad, Kamarul Azmi Jasmi (2011) Penyeliaan guru dalam pengajaran dan pembelajaran. UTM Press, UTM, Skudai.

[4] Shamsul Arrieya Ariffin. 2011. Mobile learning in the institution of higher learning for Malaysia students: Culture perspectives. Proceeding of the International Conference on Advanced Science, Engineering and Information Technology. $14-15$ Januari 2011, Hotel Equatorial Bangi-Putrajaya, Malaysia.

[5] Norazilawati Abdullah, Noraini Mohd Noh, \& Nik Azmah Nik Yusuf. 2013. Aplikasi persekitaran pengajaran maya (Frog VLE) dalam kalangan guru sains. Prosiding 7th International Malaysian Education Technology Convention (IMETC). Hotel Golden Flower Bandong. 16-18 September

[6] Norbayah Mohd Suki \& Norazah Mohd Suki. 2010. The usage of mobile device for learning: A case study. IJUTFD, 1 (1): 111. Oluwafisayo

[7] Yahya Othman \& Roselan Baki. 2008. Aplikasi komputer dalam pengajaran bahasa: penguasaan guru dan kekangan dalam pelaksanaan. 1st International Malaysian Educational Technology Convention.

[8] Zamri Mahamod \&Mohamed Amin Embi. (2008). Teknologi Malumat dan Komunikasi dalam pengajaran dan pembelajaran Bahasa Melayu: teori dan praktis. Shah Alam: Karisma Publications Sdn. Bhd.

[9] Zamri Mahamod \& Nur Aisyah Mohamad Noor. (2011). Persepsi guru tentang penggunaan aplikasi multimedia dalam pengajaran komponen sastera bahasa Melayu. GEMA OnlineTM Journal of Language Studies, 11(3), hlm163-177. 